\title{
Justifying private schools
}

\begin{abstract}
The paper looks at arguments for and against private schools, first in general and then, at greater length, in their British form. Here it looks first at defences against the charge that private schooling is unfair, discussing on the way problems with equality as an intrinsic value and with instrumental appeals to greater equality, especially in access to university and better jobs. It turns next to charges of social exclusiveness, before looking in more detail at claims about the dangers private schools pose for democratic government. It then examines complications arising from shifts in the notion of 'private' education since the 1980 s, before concluding, in the light of recent articles in JOPE about criteria for admission to university, with a discussion of Brighouse's proposal for the reform of private schooling. There are also shorter discussions of other suggestions for such reform.
\end{abstract}

A grammar school boy from Leeds, Alan Bennett first encountered the privately educated when he sat a Cambridge scholarship examination in 1951.

That weekend was the first time I had come across public schoolboys in the mass and I was appalled. They were loud, self-confident and all seemed to know one another, shouting down the table to prove it while also being shockingly greedy. Public school they might be but they were louts. Seated at long refectory tables beneath the mellow portraits of Tudor and Stuart grandees, neat, timorous and genteel we grammar school boys were the interlopers; these slobs, as they seemed to me, the party in possession.

Bennett 2014

Less colourfully, he goes on to say

Private education is not fair. Those who provide it know it. Those who pay for it know it. Those who have to sacrifice in order to purchase it know it. And those who receive it know it, or should. And if their education ends without it dawning on them then that education has been wasted.

Is Bennett right? Is private education a bad thing? And if so, is this because it is unfair? 


\section{Private schools in general}

If we consider private education in general, it is hard to see that it is necessarily unfair, or, indeed, in other ways reprehensible.

Suppose all state schools are doing a good job and are popular with parents. Suppose, too, that the few private schools that happen to exist are those that parents want for what others see as idiosyncratic reasons, even though the education they provide is, by anyone's reckoning, mediocre. Parents do not choose them for class size, since sizes are comparable with those in state schools; or for exam results, for these are poor. They prefer them because they themselves went there, say, or because the schools provide extra religious instruction in the beliefs of their own sect.

The scenario is perhaps not realistic. But it helps us to see that unfairness would be a hard charge to level against our imaginary examples. We can only make a charge of unfairness stick if privately educated children gain some kind of significant advantage that state school students lack. I stress 'significant' because if the advantage were trivial - for instance, that all the private schools in our imaginary society were just slightly more spacious than state schools - the cry 'Unfair!' would be unlikely to be heard.

More generally, it is hard to make a case in principle against allowing parents to pay for their children's schooling. People should be free to do what they want with their own money as long as this causes no harm to others. This is a specification of the principle of liberty, as formulated by Mill, that lies at the heart of liberal-democratic thinking. Private schooling is unobjectionable as long as it does not harm others. (Cohen 1981).

If this is right, there is no in-principle reason why private schools should not exist.

\section{Private schools in Britain}

Could Alan Bennett be right in his opposition to private education if he is thinking of the form this takes in Britain, rather than in an in-principle way?

\section{Unfairness}

Is he right that it is unfair? We saw, when examining in-principle arguments, that for this charge to stick, those who go to private schools must - as a necessary condition - gain some kind of significant advantage over those who do not. In Britain private students have 
more individual tuition, are in smaller teaching groups, have better facilities, have richer curricular and extra-curricular opportunities, do better at A levels, are more likely to get into universities, especially the more highly-rated ones, and figure disproportionately well in lists of those with the best jobs.

Are these and the other advantages enough to justify the charge of unfairness? If something is unfair, that suggests it is morally wrong. Is this true of the extra benefits that private schools bring?

Their defenders may argue that wanting to remove or at least reduce these differences between the two sectors betrays an ideological attachment to egalitarianism. This ideal is everyone should have the same. But, they may say, there is no good reason to believe this. Making people's lives, goods, opportunities more equal does not necessarily bring about a benefit to anyone. For suppose that, while state school provision remained the same, the better provision in private schools were reduced by fifty per cent. No one would be benefited by this move. A reply might be that the benefit would lie in the greater equality itself, since equality is intrinsically valuable. But it is presupposed to something's being of intrinsic ethical value that it is beneficial to at least one person. This is true if we are talking of the intrinsic value of autonomy, intimate relationships, helping those in distress, enjoying music or any other such value. Engaging in an intimate relationship, for instance, is valuable in itself, and this could not be so if a conceivable instance of it benefited no one. The fact that in our example of equality as an intrinsic good nobody became better off is a reason for concluding that equality is not valuable in itself ( $\operatorname{Raz} 2008){ }^{1}$

I agree with this anti-egalitarian argument, having long held that what is important is not that everyone is equal (in, for instance, wealth or educational attainment), but that everyone has enough of whatever good is necessary to equip them to lead a flourishing life (White 1994). Like several others, in other words, I have espoused a 'sufficientarian' or 'adequacy' view in preference to an egalitarian one. ${ }^{2}$ In saying this, I am excluding the democratic notion of political equality embedded, for instance, in the notion of one person, one vote. Here, as is further illustrated below, I am still a wholehearted egalitarian.

Holding an adequacy view leaves open the possibility that moves towards greater equality can sometimes be instrumentally, as distinct from intrinsically, valuable. Reducing the advantages that private schools possess, like smaller classes and better facilities, may in some way be a means of benefiting existing state school pupils whose education falls below an adequacy criterion.. But this would have to be shown, not assumed, to be the case.

Building on a suggestion made earlier, suppose every child who goes to a state school gets a pretty good deal. Although this is not as good as at Harrow or Eton or even at little-known St Mary's Convent, it still means that they enjoy school, do well in their exams, are able to go to higher or further education if they want to, and manage to secure a fulfilling and adequately paid job. Why not leave the more fortunate with all they have, given that no one else is getting a raw deal? 
That might be fine in theory, an opponent may reply, but the real world is not like that. Many in Britain today live in poverty and their children tend to go to inadequate schools. It simply is not fair that they have such a poor start in life, while Harrovians enjoy their ninehole golf course en route to Trinity College Cambridge and life as a High Court judge.

A defender of private education might reply as follows:

'It cannot simply be assumed that private schools are somehow responsible for this failure in meeting an adequacy criterion. If it is poverty we need to reduce, let us work out the best ways of doing that, rather than being diverted by how much better other people are doing. If schools in poor areas are not generating the exam results that get underprivileged youngsters into Oxford and Cambridge, it is there that we should be concentrating our efforts.

Left-wingers may still dwell on their comparisons. But it is irrational to brood on these, given that the other approach is so much more task-focused. One can only think that it must be some sort of envy that is driving them. They see all the superb teaching, the Olympic running tracks, the sparkling A level results....and dream that they or the downtrodden for whom they speak also had these things.'

This accusation of envy is often heard in these debates. I suspect it is not based on empirical evidence as much as speculation. But the more central argument, that if poverty is the problem we should direct our thoughts to that, is telling. If the opponent of private education could show that the only way, or the most effective way, of tackling it is by removing resources from the better-off, this would seem a strong counter-argument. But could he or she show that? We know that there are other ways of lifting people out of poverty, like economic growth. Whether, or how far, redistribution of wealth is also necessary - to alleviate not only extreme want, but also other causes of distress like lack of free time - is a further question. It takes us far beyond arguments about private education in particular and into general politics.

There is another, more narrowly focused, kind of 'egalitarian' challenge that has to be met. The argument is built around the claim that education is in part a positional good.

What matters is not how much education one gets, or how good that education is, or even one's results, but one's position in the distribution of those things. Children who, by going private, do better than they would have done at a state school are gaining competitive advantage over others. They are jumping the queue for university places and well-paid or interesting jobs.

(Swift 2003: 23)

Statistics seem to back this up. In 2010/11, 'an estimated 86 per cent of pupils from English private schools progressed on to a university course compared with 70 per cent of those 
from the state education system....But the gulf was even wider (for) "the most selective" universities...64 per cent of students from private schools went on to Russell Group universities in 2010/11, compared with 24 per cent from state schools.' ${ }^{3}$

It may seem clear from Swift's argument and these data that state school students are being harmed through being worsted in the competition. But there are complications over what counts as 'harm'. If this is tied to a concept of wellbeing based on the satisfaction of one's major preferences, then some state school students ambitious to get into university (or a good university), or to land a top job, are indeed likely to be harmed if their chances of doing so are lessened.

But if wellbeing is understood in terms of engagement in intrinsically worthwhile relationships and activities, the situation is more open. It could be that all or some students students said to be prevented by private school competition from getting into a Russell Group university or top job still have lives of great wellbeing. If so, it is hard to see how they have been harmed.

Elizabeth Anderson (2004) has made a more fundamental challenge to Swift's 'queuejumping' claim. She draws attention to the background assumption it involves - that there should be meritocratic equality of opportunity. This requires that competitive, or positional, goods like a university place or an attractive job should be awarded solely on the basis of an applicant's abilities and motivation, not on other things like their social class or the wealth of their parents. The abilities and motivation in question are 'developed' qualities, not innate ones. According to meritocratic equality of opportunity, a candidate for a job or any other positional good is to be judged on the abilities and motivation he or she brings to the post, not on alleged genetic qualities. Privately educated students may well have their abilities and motivation developed through their schooling; but if they do better than other applicants at getting into university or sought-after employment solely as a result of this, there is nothing unfair about what occurs.

Brighouse and Swift (2009) have replied to a similar objection from Debra Satz (2007), who has followed Anderson's lead. They agree that 'it is developed, rather than natural, talent that is relevant to who should be allocated to positions in society'. They also say that 'it is unfair if similarly talented and motivated people get different educational input' - which is in line with the quotation from Swift. They seem to see this unfairness as based on the meritocratic principle above, but, if so, like Anderson and Satz, I cannot see that any such justification could be sound, since the principle applies here to the allocation of university places and jobs, not to the kind of school one attends.

\section{Social exclusiveness}


A second complaint about British private education is that it is divisive. Its students live - at school and in later life - in a world apart, scarcely interacting with ordinary people, knowing very little about them, and often seeing them as inferior. This is especially true of boarders, since they live in their own gated community twenty-four seven. But it is also largely true of day students, since all the time they are in school and sometimes out of it they are interacting only with others like themselves. Bennett's Cambridge rowdies, bellowing down the table at each other, provide a vivid example of how such enclosed worlds can persist.

How far these charges are true is an empirical question. But suppose they were. Would that be enough to show that private schools were doing something wrong - that they should be curbed in some way, perhaps even abolished?

We should separate living in a world apart from looking down on people. On the first, an appeal to the principle of liberty might suggest that there is nothing wrong with leading a life apart from most people's as long as one is causing no harm. Monks, nuns and scholars often do this, but we do not look askance at them for that. If ex-private school pupils prefer to fraternise among themselves and their doing so does not make other individuals' lives any less flourishing - as these can still get on with their own concerns without interference what room is there for moral censure?

The second charge looks more reprehensible. It is indeed wrong to lord it over other people, to see oneself as a superior being. But insofar as the privately educated are guilty of this and we do not know how many, if any, of them might be - they are no different from many more ordinary people who look down on immigrants, benefits scroungers, blacks, blue collar workers, those in social housing. Wanting to reinforce one's place in the social pecking order is a common human desire. If it is undesirable, as I believe it is, it would need much more than a campaign against private education - a revolutionary change in social attitudes, in fact - to combat it. The focus broadens to a possible need for wider social reform, just as it did when we were discussing on $\mathrm{p}$. $\bullet$ whether or how far we should redistribute wealth and income so as to reduce the poor education and life chances of those in most need. Private education ceases in each case to be the central target of critique. Even if there were no private education, we would still have to think about how to reduce feelings of social superiority and about whether redistribution is the way forward in combating poverty.

So far, we have examined two complaints against private schooling - that it is unfair, and that it leads to social divisiveness. There is a third, and in my opinion more telling objection.

\section{A ruling class?}


'In 2007 Sutton Trust research found that over half of 500 people holding leading positions in law, politics, medicine, journalism and business were privately educated' ${ }^{4}$ The predominance was confirmed in Elitist Britain, the August 2014 Report from Alan Milburn's Social Mobility and Child Poverty Commission:

71 per cent of senior judges, 62 per cent of senior armed forces officers, 55 per cent of Permanent Secretaries, 53 per cent of senior diplomats, 50 per cent of members of the House of Lords, 45 per cent of public body chairs, 44 per cent of the Sunday Times Rich List, 43 per cent of newspaper columnists, 36 per cent of the Cabinet, 35 per cent of the national rugby team, 33 per cent of MPs, 33 per cent of the England cricket team, 26 per cent of BBC executives and 22 per cent of the Shadow Cabinet attended independent schools - compared to 7 per cent of the public as a whole. ${ }^{5}$

I don't know how many of these powerful figures are out of touch with the lives of ordinary people. Perhaps, because of their schooling, a lot of them are. But the argument that follows would still be cogent even if all private schools took steps, as some may well do, to bring home to their students how the other half (or 93 per cent?) live, and encouraged them to minister to their welfare.

The third reason to challenge private education is its role in producing national leaders. This has traditionally been a central aim. From the early nineteenth century until the midtwentieth, the private system made no bones about this. Over much of this period, Plato's Republic was a favoured text used in defence of a public school education - before Popper's demolition of it in The Open Society and its Enemies in 1945 (McCulloch 1991: 66-7). Its notion of a guardian class legitimated, or so it was thought, the dominance of its exstudents in public life both in Britain and in its Empire. In the more democratic age that has followed we have heard much less on these lines. Yet the data on top jobs is, as I shall show, disturbing.

A brief reacquaintance with the Platonic argument for Guardian rule once so influential in public schools will help to show why private school dominance is not tolerable. I will not go through the details of the Guardians' protracted and increasingly abstract higher education; or Plato's portrayal of them as children of gold, unlike the baser metals of other social classes; or the shaky assumption that knowledge of what is good enables one to do what is good. What is more relevant here is Plato's belief that a high-level education gives his benevolent rulers authoritative knowledge of what is in the best interests of the ruled.

If we translate this into modern terms, Guardian-equivalents may have a grasp of ethics and political philosophy, as well as other relevant political knowledge, but they need more than this. The people over whom they rule may run into many millions. There is no reason to think that one person's interests coincide with those of other people. Assuming they vary, in 
order to act for the good of all the rulers will have to know what different people's wellbeing consists in.

It is hard to see what evidence there could be for such authoritativeness. They may well have some idea of the basic conditions, like food and shelter, that have to be satisfied for any human being to lead a worthwhile life. But beyond this, given the plethora of possible ways of human flourishing, how could modern Guardians judge what is best for each?

Wolff (1996: 80) suggests that opinion polling could help them. To this, in our more digital decade, we might add the use of the internet, including social media, to discover individuals' preferences. But whether satisfying such preferences would necessarily be promoting their well-being is, as we saw when this issue came up earlier, a further question.

Suppose we ignored it and adopted a preference-satisfaction account of well-being. Should Wolff's suggestion incline us towards Platonic rule? There is still a problem. However fine the mesh of knowledge about preferences the rulers might acquire, it would still remain general, in that it could only tell them that person $A$ has preferences $a, b, c \ldots . x$, while $B^{\prime}$ s are $\mathrm{d}, \mathrm{e}, \mathrm{f} . . . . \mathrm{y}$ (etc). This would not enable them to understand what it is like from the inside to experience - to desire and feel - these things, including the specific meanings they have for the agents and the subtle interconnections between them in their lives. Insofar as the rulers made decisions on behalf of the ruled, they would be failing to respect them as individual agents (see Wolff 1996: 112). They would be treating them not as active persons, able to make their own decisions about things involving themselves, but as passive ones, ready to accept what the rulers lay down for them. This is at the heart of the argument, elaborated by J S Mill (1861: ch.3), for involving all individuals in government.

How does all this bear on the disproportionate numbers of privately educated people in top jobs? Like Plato's Guardians, they have been brought up with the expectation that many of them, at least, will end up in positions of power. Unlike the Guardians, they are working within the framework of a representative democracy, so there are constitutional and other legal checks on the power they wield. Neither are they the sole people in these powerful positions: state school products also hold a sizeable percentage of them. One might think these factors are enough to remove any threat that their private education might pose to democratic rule.

Yet some danger remains. The fact that private school alumni nearly all come from a similar background, and one made possible by family wealth, is relevant. It puts them in a commanding position even in occupational areas shared with a large number of state school alumni, for the backgrounds of the latter are so much more diverse. It suggests three possible threats to democratic values. One is that networks of contacts built up within and between domains of power may be used to further the interests of those in their own social group. The second is that, even without such collusion, shared assumptions deriving from a 
common background may affect, in ways hard to regulate, how well-suited they are to use their power in a way that encourages democratic agency and does not treat those outside their circle as passive recipients of the services they provide for them. The third is that, their power being based on family wealth, it is likely to continue from one generation to the next, thus reinforcing over time the first two dangers. Making top jobs more socially mixed is a way of challenging these challenges to democracy.

I have discovered that the line of thought followed in this section has close affinities with Elizabeth Anderson's (2007) article on the education of élites. This builds on her essay 'What is the point of equality?' (Anderson 1999) in which she argues for 'democratic equality' and against the most common form of egalitarianism ('luck egalitarianism') that holds that 'the fundamental aim of equality is to compensate people for undeserved bad luck - being born with poor native endowments, bad parents, and disagreeable personalities, suffering from accidents and illness, and so forth' (p.288). 'Democratic equality' is built around a combination of two ideas, both already encountered above: the familiar democratic principle that we are all equally worthy of respect; and the 'sufficientarian' or 'adequacy' view, that what is important is not that all should have equal shares of a resource, but that all should have enough of it to live well. She says that

'Democratic equality guarantees all law-abiding citizens effective access to the social conditions of their freedom at all times. It justifies the distributions required to secure this guarantee by appealing to the obligations of citizens in a democratic state. In such a state, citizens make claims on one another in virtue of their equality, not their inferiority, to others.' (p.289)

And that democratic egalitarians

seek to live together in a democratic community, as opposed to a hierarchical one. Democracy is here understood as collective self-determination by means of open discussion among equals, in accordance with rules acceptable to all. (p.313)

In her 2007 paper Anderson shows how democratic equality requires that society's élites those in leadership positions in different domains - be educated very differently from at present. She is not writing specifically about Britain's private schools, but her arguments apply well to those. Her case is that if, in a democracy, we want élites that are responsive to the concerns of people in every walk of life, they must have

(i) awareness of the interests and problems of people from all sectors and (ii) a disposition to serve those interests. Effective service of those interests requires (iii) technical knowledge of how to advance these interests and (iv) competence in respectful interaction with people from all sectors' (p.596). 
Current education for élites - and this, I should add, applies not least to British private schooling - fails to provide this array of attainments. Its academic focus enables it to score well on (iii) and to a limited extent on (i). (The latter is, I think, more applicable to the USA, with its tradition of social studies teaching, than to Britain.) Elsewhere, it falls down. It fails to help élites-in-the-making both empathetically to appreciate the problems faced by those removed in social background from themselves, and to respond interactively to those problems with them. Anderson's detailed elaboration of these shortcomings leads her to claim that élites have to be drawn from every sector of the population, not from a privileged group. For this - and this brings in the sufficientarian aspect of her analysis - a just system of school education 'must prepare students from all sectors of society, and especially those disadvantaged along any dimensions, with sufficient skills to be able to participate in higher education and thereby to join the élite' (p. 597).

This, the third of our criticisms of private schooling in Britain, is the most telling. It concerns the bedrock of our common life. If none of the privately educated went into top positions (suppose all of them went in for a hedonistic life style funded by private wealth), we might still be disquieted, but would not have worries about a concentration of power in a few hands. Although we have been formally a full democracy since universal suffrage arrived in 1928, we have still, nearly ninety years later, some way to go in seeing democratic attitudes and procedures permeating areas of life below voting in elections. ${ }^{6}$ The dominance of the privately educated in key posts long predated the 1928 reform, has long outlasted it, and continues to be an obstacle to further democratization.

To add a word of caution. The criticism depends partly on data, eg from Elitist Britain, about the future leaders these schools were educating two or more decades ago (see Walford 2006: 30) and assumes that they will continue to educate these in the future. But we will not have data on the latter, of course, for some time. ${ }^{7}$

\section{Back to social exclusiveness, unfairness and parents' rights}

In the light of this central - anti-democratic - criticism, the previous objections, to do with unfairness and exclusiveness, appear more substantial, as do doubts that critics of private education may have about its supporters' appeal to parental rights.

The arguments about social exclusiveness are that the privately educated tend to live lives apart from those of ordinary people and that they see themselves as socially superior to them. (We assume here what should be questioned elsewhere, that these claims are empirically grounded). When we looked at these arguments before, we concentrated on the harm, if any, likely to be caused to individuals outside the favoured group. The antidemocratic argument adopts a communal rather than an individualistic standpoint: it is 
about dangers to a political community rather than threats to the well-being of some individuals. In this light, it is easier to make a case against social exclusiveness. If a large proportion of those in top leadership roles are out of touch with how less privileged people live and/or look down on them as inferior, this underlines the undemocratic nature of our political arrangements.

Something similar can be said about the claim that private education is unfair. Again, when we looked at this before, the angle was individualistic, about whether people not educated at private schools were being worsted by the fast-tracking these institutions provide to good universities and top jobs. Bennett's complaint about unfairness gathers force if we have our sights on restricted access to leadership roles as a threat to democracy. The more these roles are filled by a cross-section of the citizenry - not only top roles, but, following the requirements of a more participatory form of democracy, leadership responsibilities at every level of institutional life - the better, as I have shown, for our civic health.

Finally, parents' rights. We saw no strong argument against appeals to these in defence of private schools. But things may change if we look at a parent's responsibilities not only individualistically as promoting the well-being of their child, but also from a civic point of view. If the extrinsic reasons why parents choose private schooling are about furthering their son's or daughter's chances of getting a prestigious job, this may be condonable if we see these parents merely as private individuals, intent on doing their best for their child. From a democratic perspective, parents have a responsibility to bring children up to be good democratic citizens. This excludes certain ambitions they may have for them, for example that they become members of a plutocratic power-élite.

\section{Conceptual complications}

The paper has so far assumed a clear conceptual distinction between private and state schools. 'Private' has meant 'not funded by the state, but (broadly) by parents'. But can that distinction now be made? Over the last thirty years, and especially over the last five, the line between private and state education has been blurred. Like the Direct Grant School system before it, the Assisted Places Scheme that ran from 1980 until 1997 saw the state partially funding private schools. The Academies programme has, on the other hand, seen statemaintained schools partially financed by private sponsors. Like private schools, academies (including 'free schools') are independently governed and (for the most part) not subject to the National Curriculum. The erosion of the state-private borderline has meant that fully private schools have become less clear targets for criticism. As the privatisation of state education through the Academies programme has sped onwards, there has been increasing confusion about where private education begins and ends. The concept has grown fuzzy. Adding to this has been what has been termed 'marketisation' (Marquand 2013: 110). Where 'privatisation' involves state assets joining, or partially joining, the private sector, 
'marketisation' refers to state institutions buying in private services. Examples in the case of schools would be in areas like catering, cleaning, teacher education, testing and examining. All this muddies the once far clearer concept of the private.

School league tables, introduced in 1992, have further complicated the picture. Fee-paying schools (including top ones like Eton) are thereby included in a new national system along with state ones, forming a single hierarchy of school achievement as measured largely by test and examination results. Since the 1980s, private schools, many of which previously had mediocre exam results, have sought to attract parents interested in their children getting the good A levels necessary for higher education and interesting jobs. This has placed them towards the top of league tables in different localities, vying with high-performing state schools as objects of ambitious parents' attention. ${ }^{8}$

The effect of all these changes since the 1980s on arguments for and against private education has been two-fold. On the one hand, the concept of 'private' has lost its old definiteness; on the other, the old debates about private schools presupposed a binary private or public - educational landscape that is now being replaced by one based on a single hierarchy of testable achievements. Together, these have had the effect intentionally or otherwise - of making the traditional, often passionate, black-and-white battles over the rights and wrongs of private schooling seem less relevant to today's world. Involvement by Eton, Wellington College and other public schools in state school improvement schemes also helps to erode old borders.

These moves towards a new national school system in which the public/private distinction is no longer what it was may deflect attention away from the fact that, in cornering such a large share of élite higher education and leadership jobs, private schools still present a threat to democracy. The public schools - which do the most cornering - are especial beneficiaries of the new system. Around the time of the Second World War, they were under heavy fire. They were in an exposed position, tarred with the cult of leadership on which they had been reared, and copied by the Nazis (McCulloch 1991: 27-30). Now they are less visible. They are surrounded within the private sector itself by rings of schools newly adept at winning exam prizes, if not always as illustrious ones as theirs. This whole private sector is intermeshed with top state schools, and surrounded by layer after layer of decreasingly well-rated ones. The hierarchical system is the public schools' new protector.

\section{What is to be done?}

How can the threat to democracy be confronted? This is a complex practical matter with philosophical overtones. I have reviewed several suggestions in White 2015, and now give a brief account of these and others, as well as a longer account of what seems to me the one 
most worth considering, especially because it is also the one with the most philosophical interest.

Abolishing private schools is hard to justify if people are not to be prevented from doing what they want with their money without harm to others: it may well be that some private schools are totally benign. Abolition would also be hard to implement, not least because since 1953 the European Convention on Human Rights entrenches the right to private education in law.

Another suggestion is that private schools lose their charitable status and its taxation benefits. This might be worth adopting in order to reduce their numbers, but it would be likely to be at the cost of making those left even more exclusive.

If Elizabeth Anderson's argument in the section on 'A ruling class' is sound, there is a case not only for bringing private schools under the National Curriculum, but also for remodelling this so that it focuses less on traditional academic disciplines and more on the socially integrative elements she favours.

Future Conditional, a play about education running in London in 2015, took up the journalist Peter Wilby's suggestion that Oxford and Cambridge should offer a place to every secondary school in the country. ${ }^{1}$ This could help to realize Anderson's ideal of opening élites to all sections of the people.

As a variant on this that tackles private school dominance more directly, I finish by indicating what seems to me the most promising way forward. It touches on an issue recently discussed in the Journal of Philosophy of Education.

Harry Brighouse (2000) has suggested a quota scheme for private school students entering universities. The general idea, if not all his specific proposals, seems worth following up. Universities, not least Oxbridge and others in the Russell Group, are the conduit whereby these students secure a disproportionate share of leading posts. The Sutton Trust revealed, for instance, that in 2013 five élite schools, four of them private, sent more pupils to Oxford and Cambridge than nearly 2,000 schools - two thirds - in the entire state sector. ${ }^{9} \mathrm{~A}$ quota system could see the proportion of private school entrants $-42.6 \%$ at Oxford in $2012-3^{10}$ progressively reduced to something much nearer the $7 \%$ of all students who go to private schools. This might well help to lessen the numbers of private alumni in top positions and bring about more of a social mix.

\footnotetext{
${ }^{1}$ http://www.theguardian.com/education/2015/sep/14/oxbridge-elitism-school-placefuture-conditional
} 
It would not be enough on its own to achieve the full-blooded mix that Anderson wants, since the university places vacated by private school students could be filled by state school students from élite schools. Something like Wilby's proposal could complement it. A version of this from the USA is found in the admission procedures of the University of California, especially Berkeley. Rebekah Nahai (2013: 697-8) has pointed out that Berkeley 'has one of the most racially, ethnically and socioeconomically diverse student populations of any top US research university'. It achieves this by using reliable admissions data indicators that are also socially inclusive, as well as guaranteeing the top $9 \%$ of students from these schools a place in the UC system if they have met certain requirements (which differ from the standard requirements)'.

What precise form a quota system of some kind should take is a practical question. But the proposal does raise something of more philosophical interest. One objection to a quota scheme might be that it goes against the principle that universities have an obligation to admit only the best qualified candidates. On this principle, if, say $40 \%$ of the best qualified candidates (eg those with the best A level results) are from private schools, they should all be among those admitted, assuming there are enough places. Ben Kotzee and Christopher Martin (2013) - who are not, incidentally, writing about private schools - argue for the best qualified candidate principle on the grounds that since the purpose of the university is scholarship, 'one must always make admissions decisions on the basis of which applicant will make the best scholar in their discipline' (p.639). But are there good grounds for adopting this principle? Matthew Clayton (2012) is doubtful. Among the several arguments he employs is one that questions whether universities should take scholarly ability as a given. Could it be one of their functions to develop ability, he asks, as well as offering opportunities to exercise the ability one has (p.421)? Kotzee and Martin appear to hold the latter position. They advocate, for instance, the incoming student's being 'ready (based on previous learning) for the learning opportunities available at the university' (p. 637). But why rule out the development alternative? Even on their essentialist - and questionable account of the university as having the single function of promoting scholarship, a good way of achieving this may sometimes be by taking on less well qualified students and taking steps to enhance their scholarly abilities once admitted.

The discussion up to this point has been about admission to university. We need to say something, too, about entry to employment. We have seen how the percentage of private school ex-students in many top jobs has been far higher than their percentage in the population as a whole. Will reducing the proportion of them entering élite universities remove this discrepancy entirely? It may not. The networks they have built up via their privileged education and unpaid internships that are not an option for most young people, as well as a preference that some employers may have for privately educated employees, may still give them an edge. All this bespeaks the need for some kind of public monitoring of hiring practices. Could this go so far as including quotas, as for universities? This might be 
easier to arrange in areas of the public sector such as the law, medicine, and the civil service. But I do not know of any reason in principle why industry, commerce, and finance should be excluded. Given the concern that all major UK political parties have exhibited in recent years about low social mobility, they ought to consider a quota system as one possible way of making improvements.

Debate about the fairness of a quota system is likely to continue; and it would be good to see philosophers of education participating in it, as well as in further discussion, which I hope this paper may open up, about the rights and wrongs of private education and whether its British manifestation does indeed endanger the construction of a richer and more defensible form of democracy than the one we now know. ${ }^{11}$

\section{Notes}

${ }^{1}$ The claim that equality is not intrinsically valuable is about distributional equality, ie about equality in the distribution of goods (eg money, educational opportunities). It is not about equality of consideration as a moral or political principle, as enshrined, for instance in the notion of 'one person, one vote'.

2 Early supporters of the adequacy view include Raz, J. The Morality of Freedom OUP 1986; and Frankfurt, H. 'Equality as a moral ideal' in The Importance of what we care about London: Allen and Unwin 1988.

${ }^{3}$ http://www.telegraph.co.uk/education/educationnews/10229248/Private-school-pupilsmonopolising-top-university-places.html

${ }^{4}$ http://www.suttontrust.com/news/news/the-educational-backgrounds-of-500-leadingfigures/

\section{${ }^{5}$ https://www.gov.uk/government/publications/elitist-britain}

${ }^{6}$ See Arriaga (2014) for a practical guide to 'rebooting democracy' so that ordinary citizens can be more closely involved in political decision-making.

${ }^{7}$ It is true that, as Geoffrey Walford (2006: 30) reminds us, any data we have about positions filled today reflects what private schools were doing several decades back. If we are to see the effects of what they are doing now, we will have to bide our time. On the other hand, given that through its new singlemindedness in pursuing exam success the private sector is sitting prettier than ever, the likelihood is that its alumni will continue to be 
well represented among top jobs. In the light of their track record, this is even more likely to be true of the aristocrats of the private sector, the public schools.

${ }^{8}$ Before league tables came on the scene in 1992, Geoffrey Walford foresaw the way things were likely to go. He believed that 'the long-term aim, then, is a blurring of the boundaries between private and state provision.' (Walford 1990: 113-4).

\section{${ }^{9}$ http://www.bbc.co.uk/news/education-14069516}

${ }^{10} \mathrm{http}$ ://www.timeshighereducation.co.uk/news/oxford-drops-below-cambridge-on-stateschool-entrants/2012321.article

${ }^{11}$ I am especially grateful to an anonymous JOPE reviewer who put me in touch with the work of Elizabeth Anderson and Debra Satz.

\section{References}

Anderson, E. (1999) 'What is the point of equality?' Ethics 109:2

(2004) 'Rethinking equality of opportunity: Comment on Adam Swift's How Not to be a Hypocrite' Theory and Research in Education 2:2

------- (2007) 'Fair Opportunity in Education: A Democratic Equality Perspective' Ethics 117: 4

Arriaga, M. (2014) Rebooting Democracy: A citizen's guide to reinventing politics London: Thistle

Bennett, A. (2014) 'Fair Play' London Review of Books 36:12 http://www.Irb.co.uk/v36/n12/alan-bennett/fair-play

Brighouse, H. (2000) A Level Playing Field: The Reform of Private Schools London: Fabian Society

Brighouse, H. and Swift, A. (2009) 'Educational Equality versus Educational Adequacy: A Critique of Anderson and Satz' Journal of Applied Philosophy 26: 2

Clayton, M. (2012) 'On Widening Participation in Higher Education Through Positive Discrimination' Journal of Philosophy of Education 46: 3

Cohen, B. (1981) Education and the Individual London: Allen and Unwin

Kotzee, B. and Martin, C. (2013) 'Who should go to University? Justice in University Admissions' Journal of Philosophy of Education 47:4 
McCulloch, G. (1991) Philosophers and Kings: Education for Leadership in Modern England Cambridge: Cambridge University Press

Marquand, D. (2013) Mammon's Kingdom London: Allen Lane

Mill, J.S. (1861) Representative Government. Many recent editions.

Nahai, R. (2013) 'Is meritocracy fair? A qualitative case study of admissions at the University of Oxford' Oxford Review of Education 39:5

Raz, J. (2008) 'On the value of distributional equality' Oxford University Legal Research Paper Series No 41/2008 http://papers.ssrn.com/sol3/papers.cfm?abstract id=1288545

Satz, D. (2007) 'Equality, Adequacy, and Education for Citizenship' Ethics 117

Swift, A. (2003) How not to be a hypocrite: school choice for the morally perplexed parent London: Routledge

Walford, G. (1990) Privatization and Privilege in Education London: Routledge

------ (2006) Private Education: tradition and diversity London: Continuum

White, J. (1994) 'The Dishwasher's Child: Education and the End of Egalitarianism' Journal of Philosophy of Education 28: 2

----- (2015) What's wrong with private education? e-book London: Institute of Education Press

Wolff, J. (1996) An Introduction to Political Philosophy Oxford: Oxford University Press 